\title{
Analysis of RCC and PSC Bridge Deck Slabs for Various Spans
}

\author{
H. Thanushree and H. Siddesha
}

\begin{abstract}
The effect of various span are studied using finite element software SAP2000 on RC bridge decks and PSC bridge decks are analysed for dead load, live load and their combination. In the present study, IRC class AA vehicle load is considered. The bridge deck models are analysed to compute longitudinal moment, transverse moment, torsional moment and longitudinal stresses.
\end{abstract}

Keywords--- RCC and PSC Bridge Decks, Live Load, Dead Load, Finite Element Method, Span Length.

\section{INTRODUCTION}

$\mathrm{B}$ RIDGES are defined as structures, which provide a connection or passage over a gap without blocking the opening or passage way beneath. Bridges are not simply structures made out of materials, they are part of life. In many places life would be seriously disrupted, traffic would be paralyzed and business would be terribly affected if the bridges fail functioning. Hence the assessment of bridges periodically for its performance turns out to be an important task. Bridge design is an important job for any structural engineer. In the design of bridges, span length, dead load and live loads are important. The live loads have to be selected using IRC:6 - 2000 in Indian condition.

The effect of transverse prestressing of bridge decks with substantial benefits in both economy and durability are discussed in [1].Finite Element Analysis and modelling techniques of I girder highway bridges are presented in [2].Simple approaches to determine the prestressing forces that are required in a prestressed concrete bridge to satisfy serviceability conditions is explained in [3].Stress analysis of deck slabs used with integral abutment bridges due to truck loads [4]. Behaviour of steel I-girder bridge system during its construction phase is studied in [5]. The effects of construction loads and vibrations on typical RC bridge decks are investigated [6].Computer based graphical approach to construct influence profile for bridges subjected to multiple axle loads are explained in [7]. Dynamic effect of traffic actions are studied on deck slab concrete bridges using Finite Element Method [8]. Parametric studies are carried out on wheel load distribution in single span, simply supports RC slab bridges [9]. Analytical and experimental results are compared in posttensioned concrete bridge decks [10].
Nonlinear 3D Finite Element Analysis is carried out stability analysis is carried out on truss bridge [11]. Linear buckling analysis and nonlinear stability analysis is carried out on truss bridge [12]. Developed a numerical technique on PSC bridge segment to study the displacement responses [13].Flexural live load distribution factor for cast-in-place box girder bridges is evaluated in [14]. Designed T-beam girder and box girder super structure for $25 \mathrm{~m}$ span [15]. A simply supported RCC box Girder Bridge was analysed for dead load and IRC moving load. Seismic performance of deck slabs under vertical loading is explained in [17]. Analysis of prestressed highway bridge and its strengthening is studied [18]. Bridge was analyzed in flexure using SAP2000.

The aim of this work is to determine the longitudinal moment, transverse moment, torsional moment using SAP2000 Finite element software for RC deck slab and PSC deck bridges.

\section{PARAMETRIC STUDIES}

A simply supported, single span two lane RCC and PSC slab bridge decks is studied using SAP2000. The span length is varied from $10 \mathrm{~m}$ to $30 \mathrm{~m}$ in the increment of $10 \mathrm{~m}$. The bridge deck I analyzed for dead load, live load and their combination for RCC and PSC bridge decks. IRC class AA loading is considered as a live load in the present study. Table I shows geometric parameters of deck slabs.

Table 1: Geometric Parameters of Slab Bridge Decks

\begin{tabular}{|l|l|l|}
\hline Sl.No & Span $(m)$ & Width $(m)$ \\
\hline 1 & 10 & 7.5 \\
\hline 2 & 20 & 7.5 \\
\hline 3 & 30 & 7.5 \\
\hline
\end{tabular}

\section{FINITE ELEMENT MODELING}

The analysis of bridge decks are carried out using Finite Element software SAP2000. The decks are modelled using shell elements. The following parameters are provide as input to the SAP2000 software,

$\begin{aligned} \text { i. } & \text { Modulus of Elasticity }(\mathrm{E}) & =35 \times 10^{6} \mathrm{kN} / \mathrm{m}^{2} \\ \text { ii. } & \text { Poisson's ratio }(\mu) & =0.2 \\ \text { iii. } & \text { Density } & =25 \mathrm{kN} / \mathrm{m}^{3}\end{aligned}$

\footnotetext{
H. Thanushree, PG Student, Department of Civil Engineering, Siddaganga Institute of Technology, Tumkur, Karnataka, India. E-mail:thanushree49@gmail.com

H. Siddesha, Assistant Professor, Department of Civil Engineering, Siddaganga Institute of Technology, Tumkur,Karnataka, India. E-mail:siddeshahsit@gmail.com

DOI:10.9756/BIJMMI.8154
} 


\section{RESULTS AND DisCUSSIONS}

The longitudinal moment, transverse moment, torsional moment and longitudinal stresses are drawn from the Finite Element software SAP2000 for RCC and PSC bridge decks.

\section{A. RCC and PSC Bridge Decks}

\section{1) Longitudinal Moment}

The dead load moment, live load moment, and their combination is shown in Figure 1.In the present study the longitudinal moment observed is more for $30 \mathrm{~m}$ span. This is due to the reason that longitudinal moment increases with increase in span for both the decks.

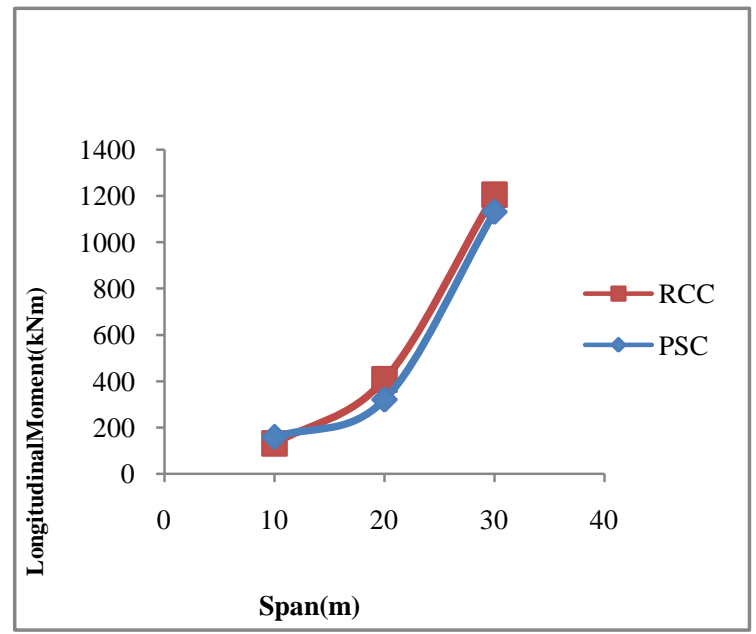

(a)

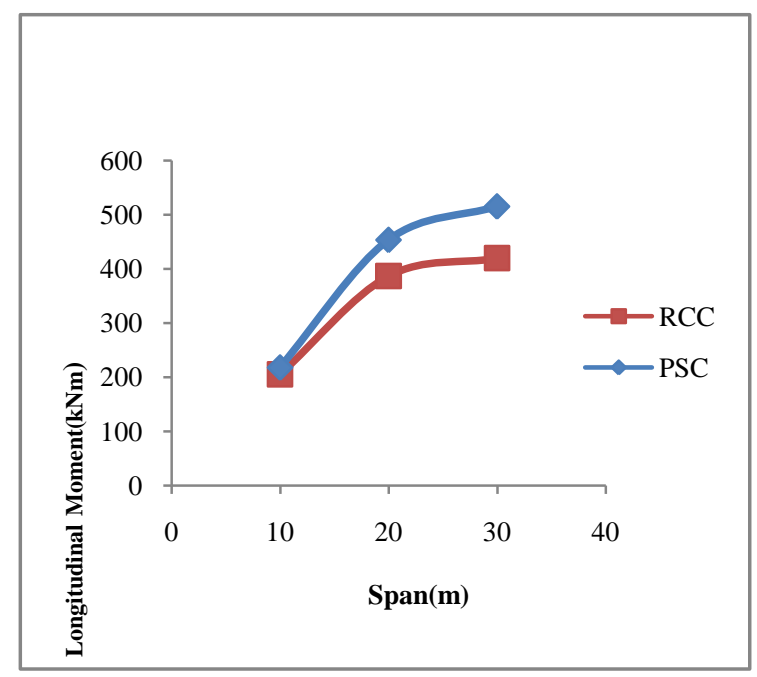

(b)

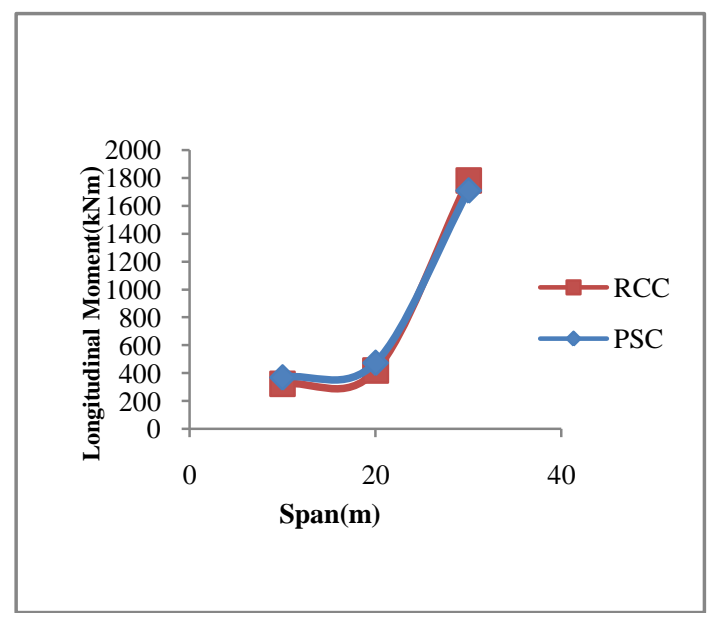

(c)

Figure 1: Longitudinal moment (a) Dead Load, (b) Live Load, (c) Dead Load+Live Load combination

\section{2) Transverse Moment}

The dead load transverse moment, live load transverse moment and their combination is shown in Figure 2 for RCC and PSC bridge decks. The transverse moment for both RCC and PSC decks are almost same.

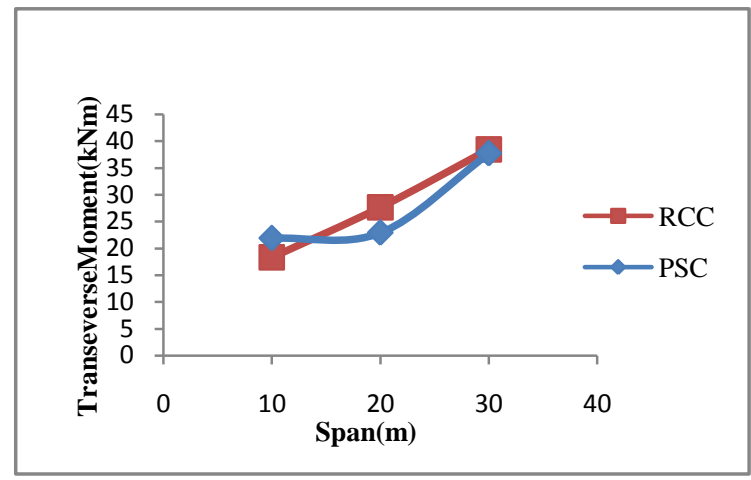

(a)

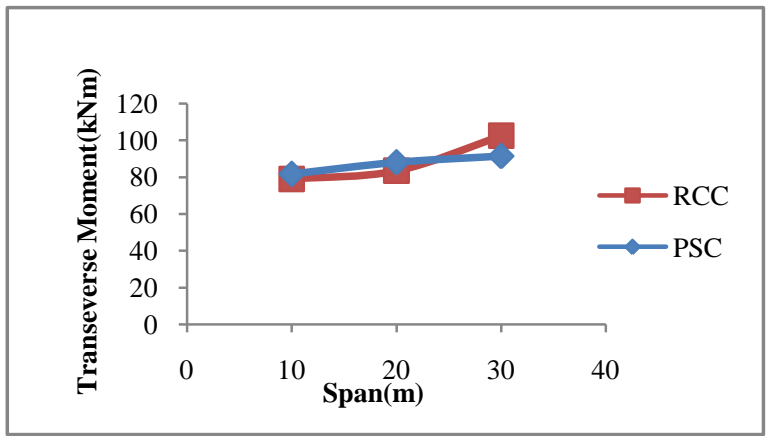

(b) 


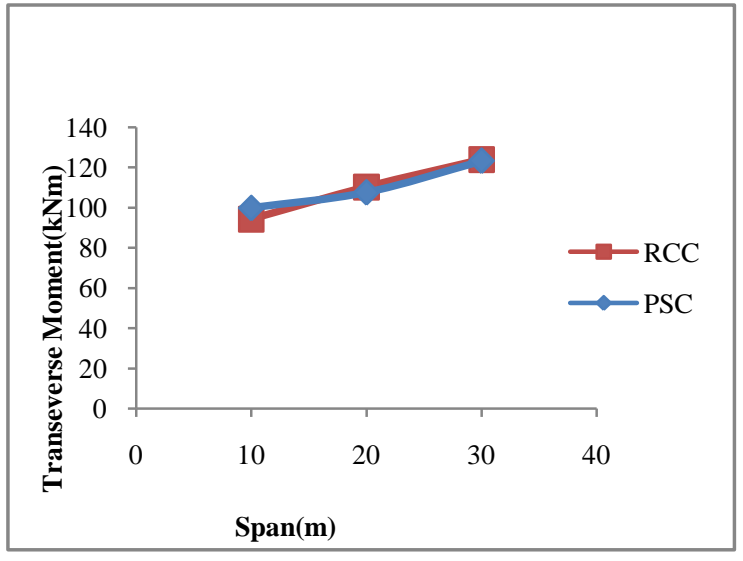

(c)

Figure 2: Transverse Moment (a) Dead Load, (b) Live Load, (c) Dead Load+Live Load Combination

\section{3) Torsional Moment}

The dead load torsional moment, live load torsional moment and their combination is shown in Figure 3. It is observed that torsional moment is more for $30 \mathrm{~m}$ span. This is due to the reason that torsional moment increases with increase in span for both deck slabs.

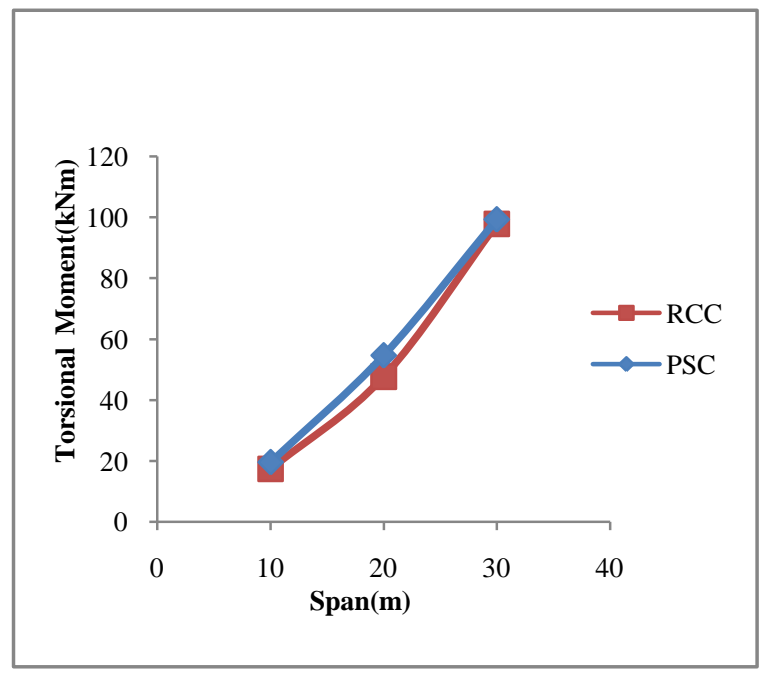

(a)

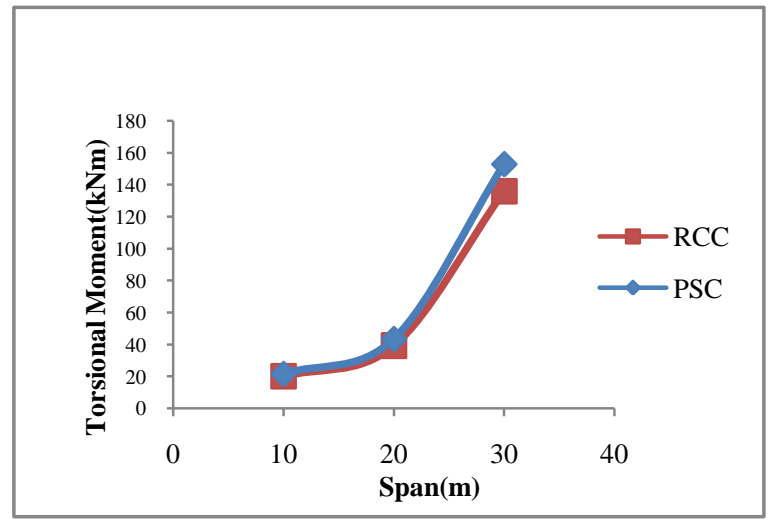

(b)

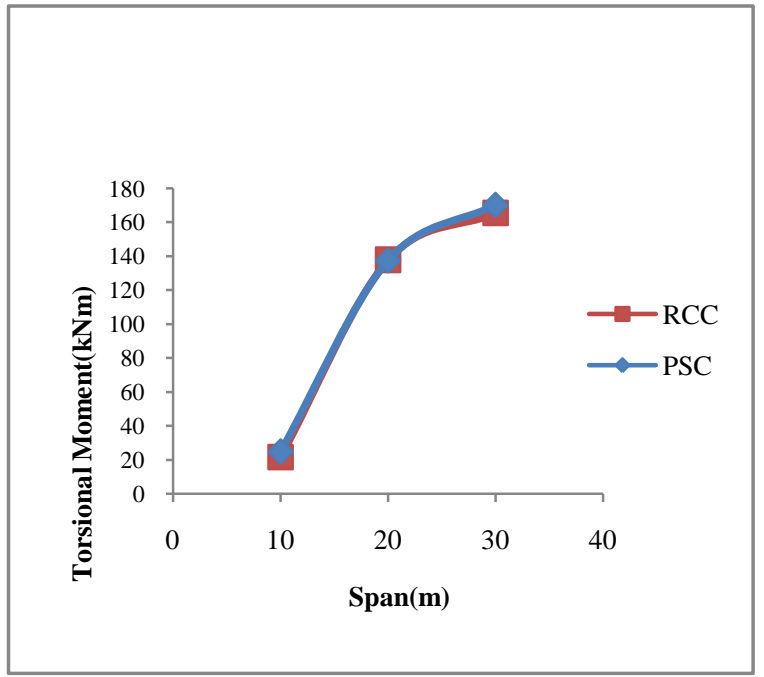

(c)

Figure 3: Torsional moment (a) Dead Load, (b) Live Load, (c) Dead Load+Live Load Combination

\section{4) Longitudinal Stresses}

The longitudinal stresses for dead load, live load and their combination are shown in Figure 4. The trend in longitudinal stresses is similar to combination of loads in longitudinal moment. It is observed that stresses increases with increase in span for both deck slabs.

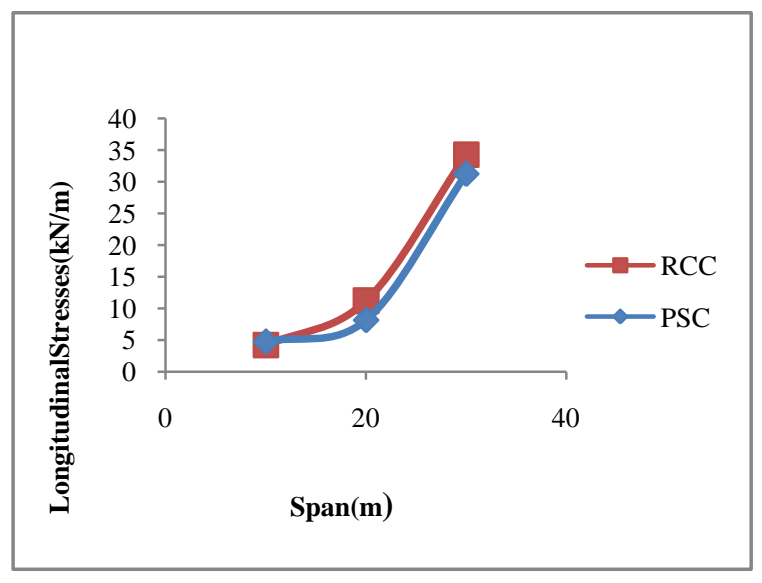

(a)

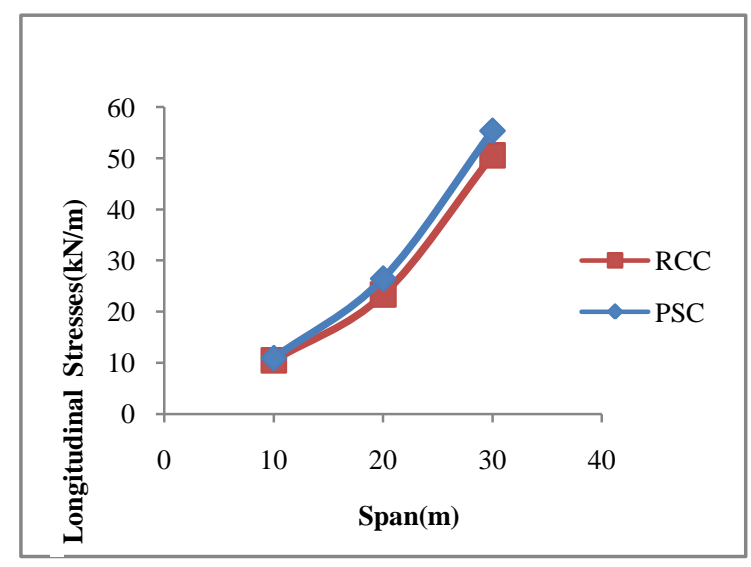

(b) 


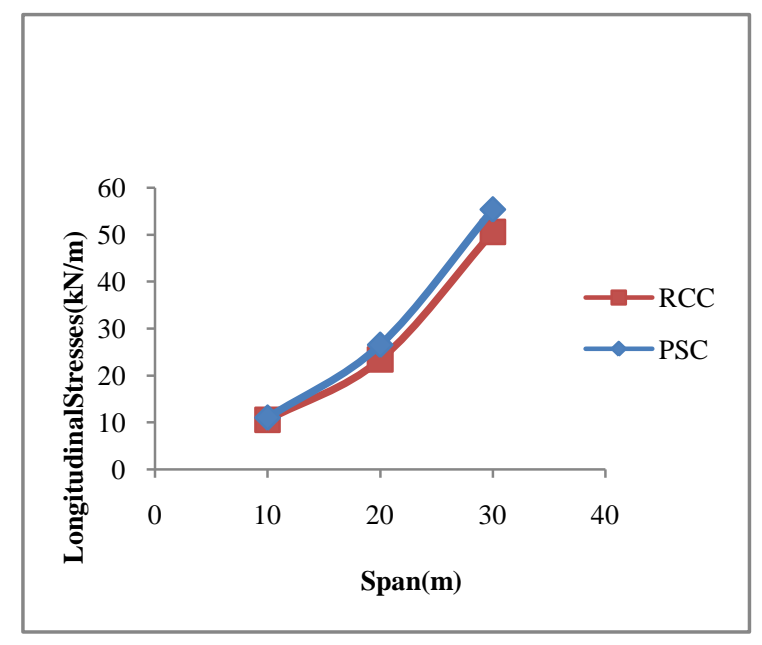

(c)

Figure 4: Longitudinal Stresses (a) Dead Load, (b) Live Load, (c) Dead Load+Live Load Combination

\section{CONCLUSION AND FUTURE ENHANCEMENT}

Based on the results obtained from numerical analysis using SAP2000, the following conclusions are drawn.

1. The longitudinal moment increases with increase in span of the bridge deck. The maximum longitudinal moments occurs at the centre of span for both RCC and PSC bridges. The variation of longitudinal moment varies from $1.5 \%$ to $2 \%$.

2. The transverse moment increases with increase in span of the bridge deck. The transverse moment varies from $3 \%$ to $4 \%$.

3. The torsional moment is found to be maximum at the corner regions. The torsional moment varies $9 \%$ to $10 \%$.

4. The longitudinal stresses increases with increase in span. It varies from $3 \%$ to $5 \%$.

\section{REFERENCES}

[1] R.W. Poston, A.R. Phipps, R.A. Almustafa, J.E. Breen and R.L. Carrasquillo, "Effects of Transverse Prestressing in Bridge Decks", Journal of Structural Engineering, Vol. 114, No. 4, Pp. 743-764, 1988.

[2] K. Tarhini and G. Frederick, "Wheel Load Distribution in I-Girder Highway Bridges", Journal of Structural Engineering, Vol. 15, No 23, Pp. 1285-1294, 1992.

[3] Andre Picard and Bruno Massicotte, "Serviceability design of Prestressed Concrete Bridges", Journal of Bridge Engineering, Vol.4, No.1, Pp. 48-55, 1999.

[4] S. Mourad and S.W. Tabsh, "Deck Slab stresses in Integral Abutment Bridges", Journal of Bridge Engineering, Vol. 4, No. 2, Pp. 125-130, 1999.

[5] T.V. Galambos, J.F. Hajjar, W.H. Huang, B.E. Pulver, R.T. Leon and B.J. Rudie, "Comparison of measured and computed stresses in a steel curved girder bridge", Journal of Bridge Engineering, Vol. 5, No. 3, Pp. 191-199, 2000.

[6] M.A. Issa, A.A. Yousif and M.A. Issa, "Effect of construction loads and vibrations on new concrete bridge decks", Journal of Bridge Engineering, Vol. 5, No. 3, Pp. 249-258, 2000.

[7] A.M. Malek and D.V. Jáuregui, "Computer-aided graphical analysis of bridges under vehicular loading", Journal of Bridge Engineering, Vol. 6, No. 3, Pp. 207-212, 2001.

[8] C. Broquet, S. Bailey. M. Fafard and E. Brühwiler, "Dynamic Behavior of Deck Slabs of Concrete Road Bridges", Journal of Bridge Engineering, Vol. 9, No. 10, Pp. 137-146, 2004.
[9] M. Mabsout, K. Tarhini, R. Jabakhanji and E. Awwad, "Wheel Load Distribution in Simply Supported Slab Bridges", Journal of Bridge Engineering, Vol. 9, No. 2, Pp. 147-155, 2004.

[10] J.P. Smith-Pardo, J.A. Ramirez and R.W. Poston, "Distribution of compressive stresses in transversely posttensioned concrete bridge decks", Journal of Bridge Engineering, Vol. 11, No. 1, Pp. 64-70, 2006.

[11] Y. Zheng, D. Robinson, S. Taylor and D. Cleland, "Finite element investigation of the structural behaviour of deck slabs in composite bridges", Engineering Structures, Vol. 31, No. 8, Pp. 1762-1776, 2009.

[12] Minhui Tonga, Fei Maoa, and Huiqing Qiua, "Structural Stability Analysis for Truss Bridge," Journal of Structural Engineering ,Vol. 16, Pp. 546-553, 2010.

[13] F.T. Au and C.C. Leung, "Full-range analysis of multi-span prestressed concrete segmental bridges," Procedia Engineering, Vol. 14, Pp. 14251432, 2011.

[14] D.J. Hodson, P.J. Barr and M.W. Halling, "Live-load analysis of posttensioned box-girder bridges", Journal of Bridge Engineering, Vol. 17, No. 4, Pp. 644-651, 2011.

[15] A. Saxena and D.S. Maru, "Comparative study of the analysis and design of T-beam girder and box girder superstructure," International Journal of Research in Engineering \& Advanced Technology (IJREAT), Vol. 1, No. 2, Pp. 2320-8791, 2013.

[16] J.M. Dulinska and R. Szczerba, "Assessment of concrete bridge performance under moderate seismic shock using concrete damage plasticity model", Procedia Engineering, Vol. 57, Pp. 1319-1328, 2013.

[17] Y.C. Choi, B.H. Oh, "Transverse Modeling of Concrete Box-Girder Bridges for Prediction of Deck Slab Ultimate Load Capacity," Journal of Bridge Engineering, Vol. 18, No. 12, Pp. 1373-1382, 2013.

[18] S.U. Khan, T. Ayub and A. Qadir, "Effect of overloaded vehicles on the performance of highway bridge girder: A case study", Procedia engineering, Vol. 77, Pp. 95-105, 2014.

[19] S. Specifications, IRC, 6-2000, "Code of practice for Road Bridges", Section-II, Loads and Stresses-Fourth Revision, 1999. 